\title{
$\mathrm{UAV}$ 용 추력편향 노즐의 정량적 특성에 관한 실험적 연구
}

\author{
박상훈*, 이 열**
}

\section{Experimental Study of the Quantitative Characteristics of Fluidic Thrust Vectoring Nozzle for UAV}

\author{
Sang-Hoon Park* and Yeol Lee** \\ Department of Aerospace \& Mechanical Engineering, Graduate School, Korea Aerospace University* \\ School of Aerospace \& Mechanical Engineering, Korea Aerospace University**
}

\begin{abstract}
Experimental study for supersonic co-flowing fluidic thrust vectoring control utilizing the secondary flow is performed. The characteristics of the thrust vectoring of two dimensional supersonic flow (Mach 2.0) are studied by Schlieren flow visualization and highly-accurate multi-component force measurements using the load cells. It is observed that the thrust deflection angle initially decreases and increases again forming a V-shaped variation as the pressure of the secondary flow increases. Characteristics of the performance coefficients of the system are also studied, and the detailed operating conditions for higher performance of the technique are suggested.
\end{abstract}

\section{초 록}

이차유동을 이용한 초음속 동축류 추력편향 제어기법에 대한 실험적 연구가 진행되었 다. 쉴리렌 유동가시화 및 로드셀을 이용한 고정확도의 다분력 시험장치를 통하여 이차원 초음속(마하수 2.0) 유동의 추력편향 특성이 관찰되었다. 추력편향각은 부유동의 압력이 점 차 커지면서 일시 감소 후 다시 증가하는 $\mathrm{V}$-자형 추세를 보이고 있음이 관찰되었다. 추력 편향 유동의 성능을 나타내는 성능계수들의 분석이 이루어졌으며, 보다 높은 성능지표를 나타내는 본 시스템의 운용조건이 제시되었다.

Key Words : Thrust Vector Control(추력편향제어), Co-flow(동축류), Coanda Effect(코안 다 효과), Supersonic Flow(초음속 유동), Thrust Performance Coefficient(추 력성능계수)

\section{I. 서 론}

최근 들어 무인전투기의 고기동성, 고효율 제 어를 위한 새로운 추력편향 제어기술이 요구되고 있다. 이러한 추력편향 제어기술은 기존의 조종

† Received: March 21, 2014 Accepted: July 27, 2014

** Corresponding author, E-mail : ylee@kau.ac.kr
면을 대체하여 비행체의 스텔스 기능을 향상 및 고기동 성능의 확보를 목표로 한다.

과거 기계적 추력편향 제어방법은 복잡한 구 조 및 증가된 무게로 무인기에 적용하기에는 한 계가 있어, 최근 부유동(이차유동)을 활용하여 주

http://journal.ksas.or.kr/

pISSN 1225-1348 / eISSN 2287-6871 
유동을 편향시키는 유체역학적 추력편향 제어방 식이 관심의 대상이 되고 있다. NASA Langley Research Center의 연구자료[1]에 의하면, 이러한 유체역학적 추력편향제어 기술의 적용으로 엔진 무게 당 추력성능을 7 12\% 정도 개선할 수 있고 또한 노즐수명 연장에 따른 37 53\% 정도의 운용 비용 절감이 가능하다고 보고된 바 있다.

유체역학적 추력편향 제어기법의 하나로 코안 다(coanda) 효과를 이용하여 유동을 편향시키는 방법들이[2-6]이 있다. 이 방법은 다른 유체역학 적 추력편향 방법과 비교하여 시스템이 갖는 구 조가 비교적 간단하며 추력손실이 크지 않은 것 으로 평가되고 있다. 이러한 코안다 효과를 이용 하는 추력편향 제어기법 중에서 코안다 부유동의 방향과 주유동의 방향이 일치하는 동축류 (co-flow) 방법은 과거 아음속 범위에서 일부 연 구 $[3,4]$ 가 진행된 바 있고, 초음속 유동 경우에 는 대향류(counter flow) 조건에서 연구 $[5,6]$ 가 진행된 바 있다.

이에 따라 과거 당해기관에서 코안다 효과를 이용한 초음속 '동축류' 추력편향 제어에 관한 연구를 진행한 바 있다. 수치해석적 방법 및 유 동가시화를 이용한 정성적인 추력편향 특성이 관 찰되었으나[7], 그 결과가 정성적이라는 한계가 있었다. 이에 보다 정확하고 정량적인 추력편향 특성을 관찰하기 위하여 높은 계측 정확도를 갖 는 다분력 시험장치가 개발된 바 있다[8].

본 연구에서는 기 개발된 추력편향 측정장치 를 이용하여 다양한 유동변수 변화에 대한 동축 류 방식의 추력편향 특성을 실험적으로 관찰하였 다. 유동가시화를 이용한 충격파를 동반한 노즐 후방 유동구조에 관한 정보가 확보되었고, 유동 의 비정상성, 그리고 추력편향효율[9]과 관련된 정량적 성능지표가 도출되었다.

\section{II. 실험장치 및 방법}

\section{1 실험장치}

Figure 1은 본 연구에 사용된 추력편향시험장 치의 노즐 출구면을 나타내고 있다. 그림에는 주 노즐을 통과하는 주유동(일차유동)의 전압 및 부 노즐을 통과하는 부유동(이차유동)의 전압이 각 각 $P_{t 1}, P_{t 2}$ 로 나타나 있고, 곡률반경(R) $40 \mathrm{~mm}$ 인 코안다 플랩이 노즐출구에 위치하고 있다. 주 노즐의 출구 단면적은 $40 \mathrm{~mm} \times 10 \mathrm{~mm}$ 로 사각노 즐 형태이며, 설계마하수는 2.0 이다. 음속 노즐로 설계된 부노즐은 코안다 플랩의 이동을

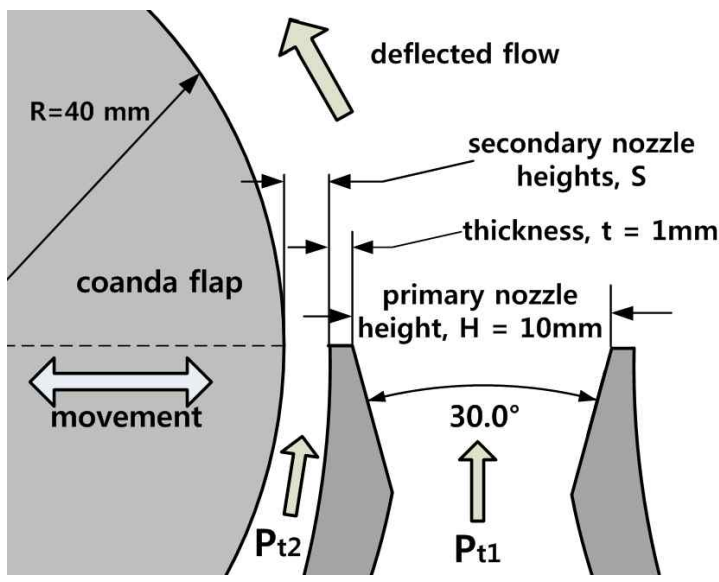

Fig. 1. Schematic of the nozzle and flap

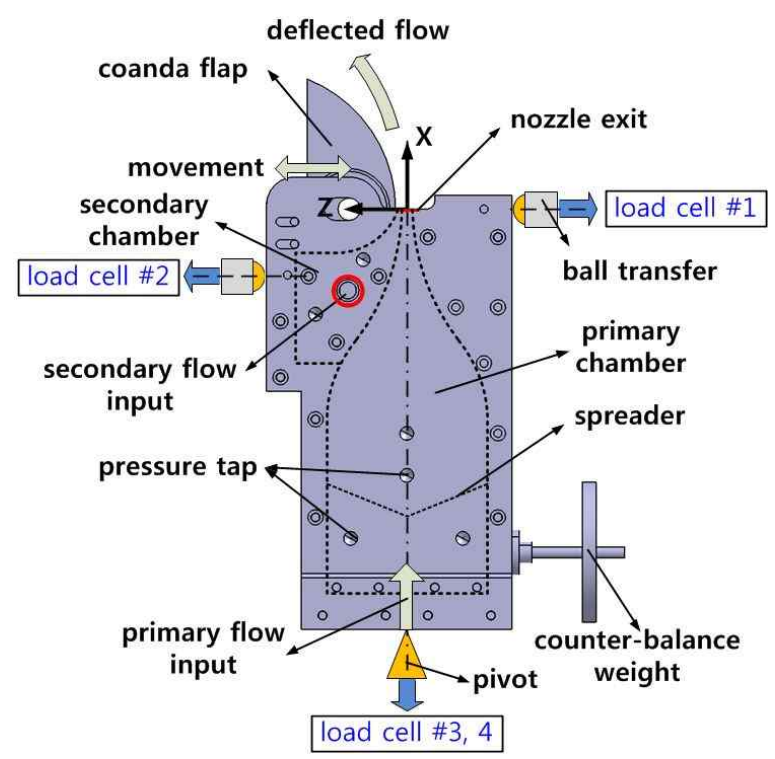

Fig. 2. Configuration of the nozzle

통해 부노즐 출구높이(s)를 연속적으로 조절할 수 있도록 되어 있다.

Figure 2는 시험장치의 노즐부 상세 개략도를 나타내고 있다. 측추력을 측정하는 빔(beam)형 로드셀(1번, 모델 $\mathrm{BCA}, \mathrm{CAS}$ 사)이 노즐 출구면을 기준으로 평행선상에 위치하며, 노즐부 중심축 하단에 위치하는 두 개의 S형 로드셀(3번과 4 번, 모델 SBA, CAS사)을 이용하여 종추력이 측정된 다. 이때 본 연구의 조건에서 실험이 진행되는 동안에 2번 로드셀에는 하중이 인가되지 않는다. 본 연구에서 사용되는 시험장치에 관한 매우 자세 하고 정밀한 측정오차 해석이 이루어진 바 있다. 그 결과 설치된 로드셀 간의 상호간섭이 가장 큰 측정오차를 만들어내는 것으로 밝혀졌으나, 그 측 정오차의 크기는 $5 \%$ 미만으로 평가되었다. 본 연 구의 실험장치 및 측정오차에 관한 보다 자세한 
설명은 참고문헌 [8]에 제시되어 있다.

\section{2 실험방법}

유동구조의 정성적 분석을 위하여 설치된 쉴 리렌(Schlieren) 유동가시화장치 및 동조화된 자 료획득장치의 구성이 다음 Fig. 3에 나타나 있다. 두 개의 쉴리렌 거울(직경 $125 \mathrm{~mm}$, 초점거리 $1000 \mathrm{~mm}$ )과 두 개의 평면거울을 통해 Z-형태의 쉴리렌 구성과 함께 펄스광원(LS-201, $\mathrm{KOMI}$ 사) 및 CCD 카메라(CCE-B013-U, Mightex사)가 사용 되었다. 주유동의 분출과 동시에 NI 9474(NI사) 를 통해 $1 \mathrm{~Hz}$ 의 트리거 신호를 발생시켜 광원과 $\mathrm{CCD}$ 카메라를 동조시켜 쉴리렌 영상을 획득하 였다. 압력신호 $(1 \mathrm{ksamples} / \mathrm{s})$ 와 로드셀의 분력신 호(2ksamples/s)는 LabVIEW를 통하여 획득되어 자료처리에 사용되었다.

실험은 주유동이 과대팽창(overexpansion)되는 조건(NPR1=3.0 5.0)에서 다양한 부유동 압력조건 (NPR2=1.5 3.5)의 조합으로 진행되었다. 여기서

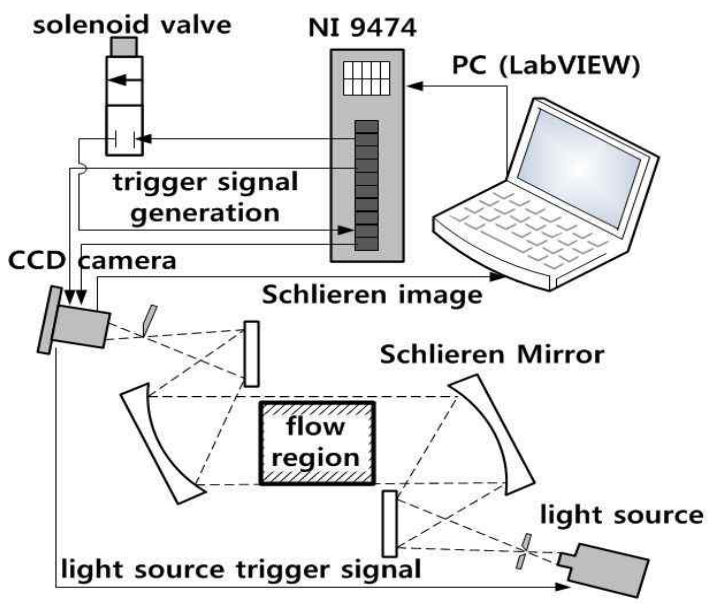

Fig. 3. Data acquisition system

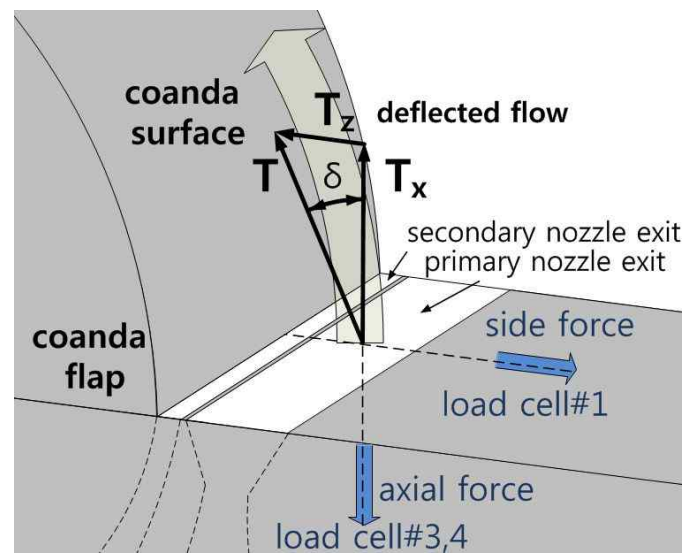

Fig. 4. Schematic of the thrust directions
$\mathrm{NPR} 1\left(=P_{t 1} / P_{b}\right)$ 은 대기압에 대한 주노즐 전압 의 비이며, $\operatorname{NPR} 2\left(=P_{t 2} / P_{b}\right)$ 는 대기압에 대한 부 노즐 전압비를 나타낸다. 유동의 분출순서는 이 력현상[7]에 의한 오차를 방지하기 위하여, 주유 동 분출 후 부유동 분출의 순으로 진행되었다.

Figure 4 에는 노즐 출구면에서의 힘의 방향이 제시되어 있다. 출구면과 동일한 선상에 위치한 로드셀(1번)로부터 측추력 $\left(T_{z}\right)$ 을 측정하고 노즐 부 중심축 하단에 위치한 로드셀(3번, 4 번)로부터 종추력 $\left(T_{x}\right)$ 을 측정되어 다음 식 (1)과 같이 추력 편향각 $(\delta)$ 이 평가되었다.

$$
\delta=\tan ^{-1}\left(\frac{T_{z}}{T_{x}}\right)
$$

\section{III. 결과 및 고찰}

\section{1 단일 코안다유동의 편향특성}

유동의 편향을 발생시키기 위한 제어유동으로 서 단일 부유동의 코안다 효과를 검증하였다. 다음 Fig. 5에는 곡률반경 $40 \mathrm{~mm}$ 의 코안다 플랩 과 부유동 출구높이(s) $2 \mathrm{~mm}$ 에서의 단일 부유동 (이 경우 주유동은 분출되지 않음)의 쉴리렌 유 동가시화 결과가 제시되어있다. Fig. 5-(a)에는 $\mathrm{NPR} 2=1.5$ 인 경우가, Fig. 5-(b)에는 NPR2=3.5인 과소팽창된 부유동의 경우를 나타내고 있는데, 영상을 통하여 분출된 부유동이 코안다 플랩 후 방면까지 잘 부착되어 흐르고 있음을 확인할 수 있다. 아울러 부유동의 전압이 커지면서(NPR2 증가) 시험장치의 로드셀로 직접 측정되어 평가 된 추력편향각 $(\delta)$ 은 33 도에서 42 도로 증가하여, 부유동의 코안다 효과가 강하게 존재함을 확인할 수 있다.

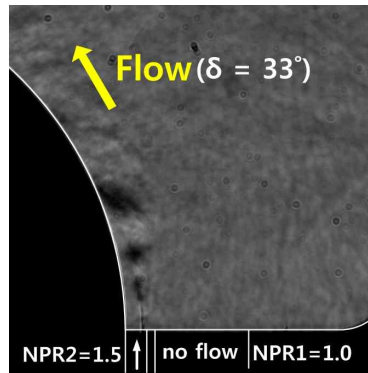

(a)NPR2 $=1.5$

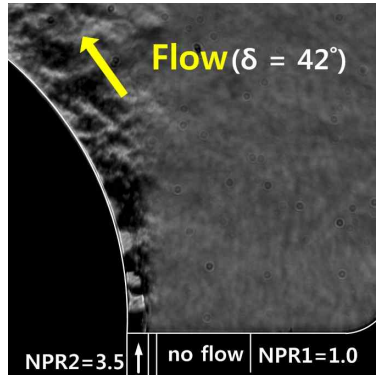

(b)NPR2=3.5
Fig. 5. Schlieren visualizations of single secondary jet $(s=2 \mathrm{~mm})$ 


\section{2 로드셀 신호로 본 유동의 비정상성}

본 연구에서 관찰하는 고속유동은 내재적으로 강한 비정상성을 가지고 있으리라 판단되는 바, 로드셀 (응답속도 약 $100 \mathrm{~Hz}$, [10])에서 측정되는 신호를 통하여 그 특성을 관찰하여 보았다. 다음 Fig. 6에는 NPR1=5.0, NPR2=3.0의 실험조건에서 얻어진 종추력 $\left(T_{x}\right)$ 과 측추력 $\left(T_{z}\right)$ 의 로드셀 신호 가 제시되어 있다. 실험은 우선 주유동을 분출시 켜 정상상태에 이른 후 미리 원하는 전압으로 세 팅된 부유동의 연결밸브(solenoid valve)를 여는 방식으로 진행되었다. 따라서 연결밸브의 조작시 로드셀 신호의 급격한 변화가 관찰되고 있는데, 이후 모든 로드셀 신호는 곧 준정상상태(quasi steady)에 이르는 것을 알 수 있다.

Figure 6에서 본 연구의 유동은, 제한된 응답 속도의 로드셀 신호이지만, 작지 않은 비정상성 을 가지고 있음이 확인되고 있다. 종추력의 경우 시간에 따른 로드셀 신호의 표준편차는, 부유동 연결밸브의 열림 전후로 약 $1.4 \mathrm{~N}$ 에서 약 $1.6 \mathrm{~N}$ 으 로 변하여 큰 변동이 없는 것으로 나타났다. 그 러나 측추력의 경우는 부유동 연결밸브가 열리면 서 표준편차가 $0.9 \mathrm{~N}$ 에서 $0.4 \mathrm{~N}$ 으로 감소하고 있 다. 연결밸브가 열리기 전에도 약 $15 \mathrm{~N}$ 의 측추력 이 작용하는 이유는 부유동의 분출이 없이도 노 즐출구에 자리한 코안다 플랩의 후향계단 효과 $[11,12]$ 로 인하여 주유동의 방향이 플랩방향으로 꺾이는 데에서 기인하는 것으로 판단된다. 이는 부유동이 분출되기 전 나타났던 후향계단 유동이 강한 비정상 특성이 보이고 있음을 보여주고 있 다.

실험이 진행되는 동안 로드셀 신호의 잡음 (room noise) 특성이 세밀하게 관찰되었으며, 그 결과 힘으로 환산된 신호잡음은 대략 0.20

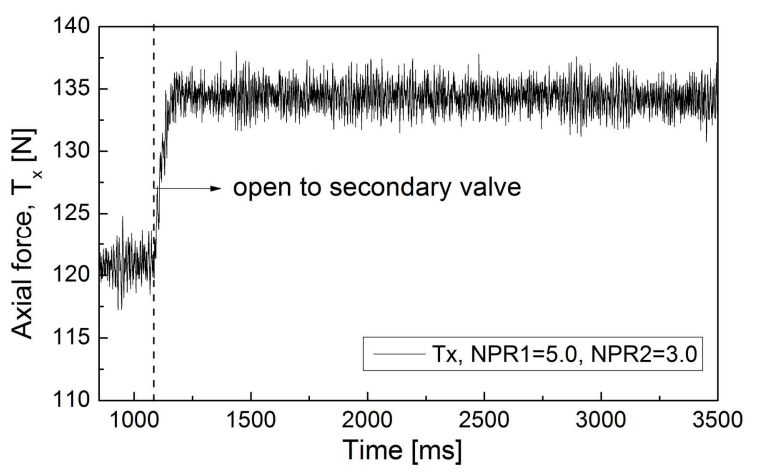

(a) axial force $\left(T_{x}\right)$

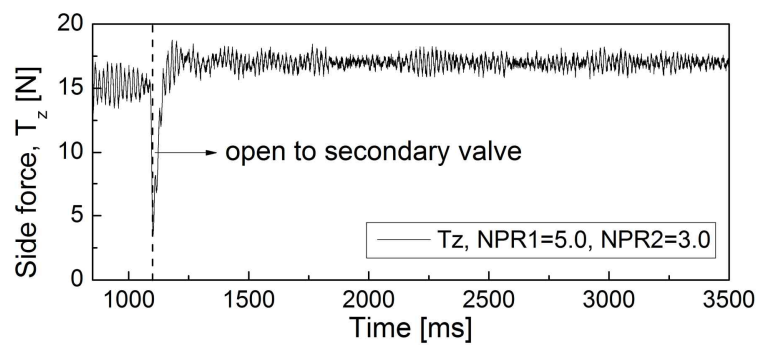

(b) side force $\left(T_{z}\right)$

Fig. 6. Timewise load cell signals

$0.34 \mathrm{~N}$ 범위에 있는데, 실제 로드셀 측정범위는 최대 $135 \mathrm{~N}$ 가까이로 커서 실제 로드셀의 $\mathrm{S} / \mathrm{N}$ 비(Signal to noise ratio)는 우수한 것으로 판명 되며, 따라서 Fig. 6에서 나타난 요동하는 신호는 잡음에 의함이 아닌 것으로 판단된다. 이러한 신 호의 잡음 및 교정과정에서 나타나는 측정오차는 미분을 이용한 불확도 계산이 진행되어 앞으로 제시되는 모든 측정결과에 에러바를 포함시켰다.

\section{3 편향유동의 가시화}

Figure 7에서는 $s=2 \mathrm{~mm}$ 조건에서 부유동과 주유동이 같이 분출되는 복합유동의 유동가시화

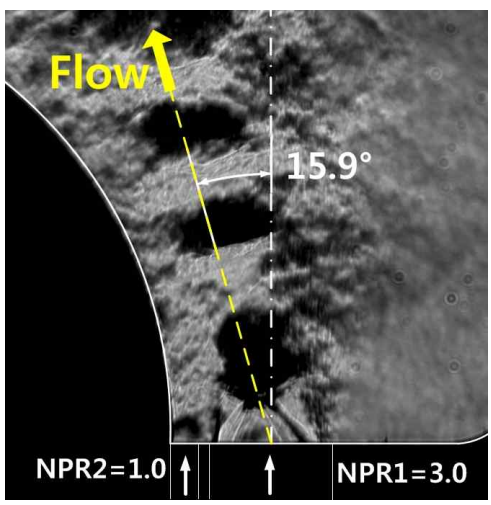

(a) NPR2 $=1.0$ (not activated)

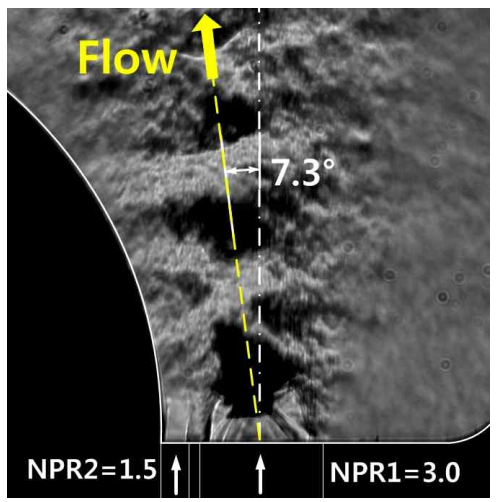

(b) $\mathrm{NPR} 2=1.5$

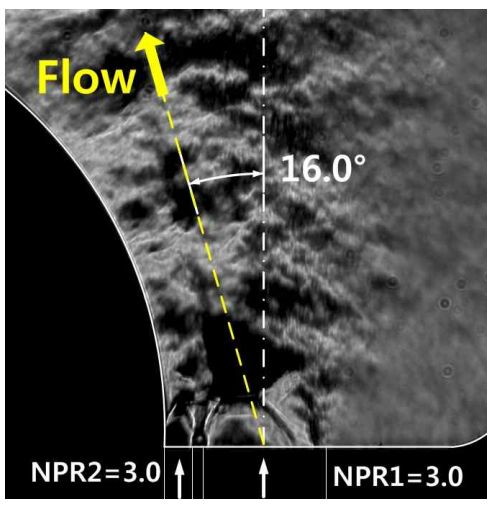

(c) $N P R 2=3.0$

Fig. 7. Schlieren visualizations for various NPR2s (NPR1=3.0, $R=40 \mathrm{~mm}, s=2 \mathrm{~mm}$ ) 
결과가 제시되어있다. Figure 7-(a)는 부유동의 공급이 없는 단일 주유동의 영상을 보여주는데, 노즐 출구에서 마하반사(Mach reflection)를 통한 충격파 및 다이아몬드 셀의 구조가 관찰되고 있 다. 그림에서 제시된 바와 같이 이때 로드셀을 통하여 측정된 추력편향각은 $15.9^{\circ}$ 로 나타났다. 이는 단일 주유동과 코안다 표면 사이에서 발생 된 재순환영역(recirculation zone)을 동반한 후향 계단 효과의 영향[11, 12]으로, 부유동이 없음에 도 주유동이 코안다 표면과 간섭하여 유동의 편 향이 이루어지는 것으로 판단된다.

하지만 Fig. 7-(b)에서 나타나듯 초킹되지 않은 부유동의 공급(NPR2=1.5)은 앞서 있었던 부유동 노즐 바로 후방에 위치하였던 재순환영역 및 이 로 인한 후향계단 효과를 불어내어 (blowing), 전체적인 유동의 편향각은 오히려 $7.3^{\circ}$ 로 작아지 는 것이 관찰되고 있다. 반면 Fig. 7-(c)에서 나타 난 $\mathrm{NPR} 2=3.0$ 의 경우처럼 부유동의 유동압력이 증가하면 이 부유동 자체의 코안다 효과가 커지 고 아울러 측정된 전체적인 편향각은 $16.0^{\circ}$ 로 다 시 증가하는 것을 볼 수 있다.

부유동의 분출이 없이도 주유동과 코안다 플 랩 사이에서 나타나는 이러한 후향계단 효과를 다양한 부노즐 출구높이(s)에 대하여 관찰하여 보았다. 그 결과, 이러한 후향계단 효과가 전체 유동의 편향각에 대해 주유동의 운동량이 커질수 록 그리고 $\mathrm{s}$ 가 커질수록 작아지고, 아울러 본 연 구의 조건에서는 $s$ 가 $4.5 \mathrm{~mm}$ 이상에서 단일 주 유동의 후향계단의 효과는 완전히 사라지는 것으 로 관찰되었다.

\section{4 추력편향 성능평가}

전체 유동에서 나타나는 추력편향각 $(\delta)$ 이 주유 동과 부유동의 운동량플럭스비에 따라 변화하는 특성이 다음 Fig. 8에 제시되어 있다. 여기서 운 동량플럭스비 $\left(C_{\mu}\right)$ 는 다음 식 (2)와 같이 노즐출 구에서의 주유동의 운동량플럭스에 대한 부유동 의 운동량플럭스의 비로 정의된다. 이때 $\dot{m}$ 와 $V$ 는 각각 질량유량과 속도를, 하첨자 $p$ 와 $s$ 는 각 각 주유동과 부유동을 나타낸다.

$$
C_{\mu}=\frac{\dot{m}_{s} V_{s}}{\dot{m}_{p} V_{p}}
$$

Figure 8에는 제시된 데이터의 최종오차 범위 가 에러바로 표시되어 있다. 최종오차 범위는 오 차에 미치는 전달체계의 미분계산을 이용하여 얻

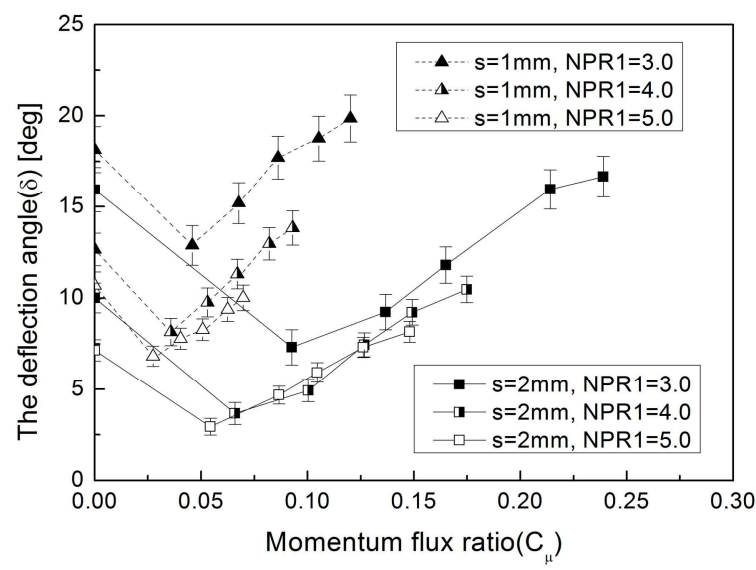

Fig. 8. Thrust deflection angle for various momentum flux ratios

어졌으며, 이때 사용된 각 항의 오차설정에 관한 내용은 참고문헌 [8]에 자세히 제시되어 있다. 아 울러 이러한 에러바는 비슷한 방법으로 후술되는 성능계수 평가에도 적용되었다. 실험결과의 재현 성 또한 검토되었으며, 동일 경계조건에서 수행 된 독립된 실험결과 모두 에러바 안에 위치하여 재현성 또한 우수하였다.

Figure 8 에서 제시된 바와 같이 추력편향각은 처음 부유동 분출이 시작되면 후향계단 효과가 사라지면서 일시적으로 편향각이 감소하다가, $C_{\mu}$ 증가에 따라 다시 증가하는 $\mathrm{V}$-자형 추세를 보이고 있음은 앞서 유동가시화 결과(Fig. 7)에서 도 설명한 바 있다. Figure 8에서 동일한 운동량 플럭스비 $\left(C_{\mu}\right)$ 에 대하여 $s=1 \mathrm{~mm}$ 인 경우가 $s=2 \mathrm{~mm}$ 인 경우보다 편향각이 크며, 아울러 동 일한 $s$ 크기에 대해서는 NPR1이 작을수록 편향 각은 크게 나타나고 있음이 보여진다.

또한 $C_{\mu}$ 증가에 따른 편향각 증가의 기울기 는 $s=1 \mathrm{~mm}$ 일 때가 $s=2 \mathrm{~mm}$ 인 경우보다 약 두 배 가까이 크게 나타나고 있어, 부유동 분출 에 의한 편향 응답성은 코안다 표면이 주노즐 출 구에 근접하게 위치될 때 더 우수한 것을 알 수 있다. 이와 유사한 결과는 과거 단일 초음속 코 안다 유동의 특성에 관한 연구[11]에서도 관찰된 바 있다.

본 연구에서는 다음 식 (3)으로 표현된 총합 추력비(resultant thrust ratio, $\left.C_{f . g . s y s}\right)[9]$ 를 정의 하고 $C_{\mu}$ 의 증가에 따른 이 계수의 변화를 관찰 하여 보았다.

$$
C_{f . g . s y s}=\frac{T}{T_{p}+T_{s}}
$$




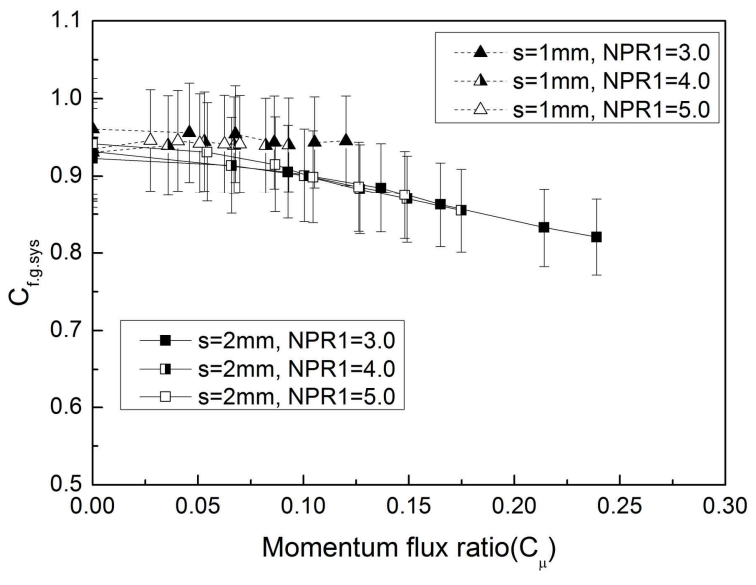

Fig. 9. Resultant thrust ratio for various momentum flux ratios

여기서 식 (3)에 나타난 $T$ 는 Fig. 4 에 나타난 종추력과 측추력의 벡터합으로 표현된 추력의 크 기로, 편향된 비행체의 유동방향으로의 추진력을 의미한다. 아울러 $T_{p}$ 와 $T_{s}$ 는 각각 실험장치의 정체실에서 측정되는 정체압을 이용하여 계산된 주유동과 부유동의 이론 추력식으로 다음 식 (4) 와 같이 나타낼 수 있다.

$$
\begin{aligned}
& T_{p}=C_{\theta} \dot{m}_{p} V_{p}+A_{e . p}\left(P_{e . p}-P_{b}\right) \\
& T_{s}=\dot{m}_{s} V_{s}+A_{e . s}\left(P_{e . s}-P_{b}\right)
\end{aligned}
$$

이때 주유동의 이론추력 평가에서 주노즐 확 장부의 확장반각 $\left(C_{\theta}\right)[13]$ 이 고려되었다. 식 (4)에 서 $A_{e}$ 는 노즐출구 면적이며, $P_{e, p}$ 와 $P_{e, s}$ 는 각 각 주노즐과 부노즐의 출구에서의 정압력이다.

다음 Fig. 9 에 $C_{f . g . s y s}$ 와 $C_{\mu}$ 와의 관계가 제시 되어 있다. 그림에서 부유동의 출구높이가 상대 적으로 작은 $s=1 \mathrm{~mm}$ 인 경우에 $C_{f . g . s y s}$ 은 $C_{\mu}$ 증가에 큰 변동이 보이지 않고 비교적 큰 값(약 0.95 내외)을 유지하고 있어 편향이 유도되는 경 우에도 추력손실은 그리 크지 않음을 알 수 있 다. 그 반면 $s=2 m m$ 인 경우 $C_{f . g . s y s}$ 은 $C_{\mu}$ 증 가에 크게 감소하여 그 값이 약 0.80 정도 까지 떨어지는 것으로 나타나고 있어 편향조건에서 일 부 추력손실은 불가피할 것으로 판단된다. 이때 그 감소의 경향은 NPR 1 의 크기와 거의 무관함 을 보여주고 있다.

부유동이 분출되는 조건 $\left(C_{\mu}>0\right)$ 에서 Fig. 8 과 Fig. 9의 결과를 비교하여 볼 수 있다. 이때 $s=1 \mathrm{~mm}$ 의 경우에는 $C_{\mu}$ 의 증가에 따라 추력 편향각은 증가하나 $C_{\text {f.g.sys }}$ 값은 일정하기 때문

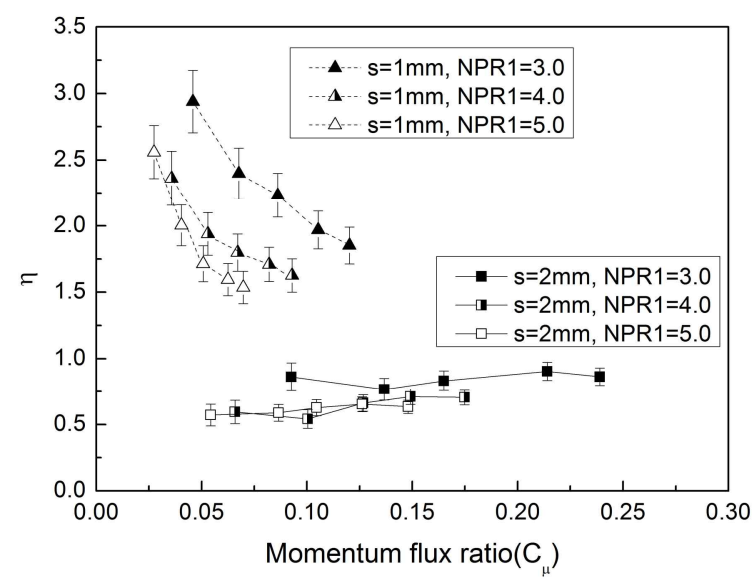

Fig. 10. Thrust vectoring efficiency for various momentum flux ratios

에 비행체가 진행하는 방향으로의 추력손실은 $5 \%$ 정도로 작게 나타나는 것으로 이해될 수 있 다. 반면 $s=2 m m$ 에서는 $C_{\mu}$ 증가에 따라 추력 편향각은 상승하고 있지만 $C_{\text {f.g.sys }}$ 값은 감소하 고 있어, 편향발생시 종추력 감소되는 정도 만큼 측추력의 상승이 동반되지 않음을 보여준다.

본 연구에서 개발되고 있는 추력편향 시스템 의 성능을 나타내는 대표적인 지표로 총합 추력 편향효율(resultant pitch thrust vectoring efficiency, $\eta$ )[9]를 정의하고 $C_{\mu}$ 의 증가에 따른 이 계수의 변화를 관찰하여 보았다. 다음 식 (5) 는 $\eta$ 의 정의를 나타내고 있다.

$$
\eta=\frac{\delta}{\frac{\dot{m}_{s} V_{s}}{\dot{m}_{p} V_{p}+\dot{m}_{s} V_{s}}} \times 100(\mathrm{deg} / \%)
$$

다음 Fig. 10 에 $\eta$ 와 $C_{\mu}$ 와의 관계가 제시되어 있다. 그림에서 부유동의 출구높이가 상대적으로 작은 $s=1 \mathrm{~mm}$ 인 경우에 $\eta$ 는 $s=2 \mathrm{~mm}$ 인 경 우보다 크며 이는 본 연구에서 관찰된 $C_{\mu}$ 의 전 범위에서 항상 성립한다. 이는 $s=1 \mathrm{~mm}$ 인 경우 에 적은 운동량플럭스비로도 보다 큰 추력편향각 을 얻을 수 있음을 나타낸다. 또한 $s=2 \mathrm{~mm}$ 경 우에는 $C_{\mu}$ 가 증가함에 따라 $\eta$ 의 큰 변동이 보 이지 않지만 $s=1 \mathrm{~mm}$ 경우에는 큰 폭으로 변 화하고 있어 운동량플럭스비 변화에 민감하게 반 응하고 있음을 알 수 있다. 아울러 $s=1 \mathrm{~mm}$ 일 때 $\eta$ 는 NPR1이 낮을수록 높은 값을 보이고 있 다.

이와 같이 본 연구에서 개발되고 있는 추력편 
향 시스템의 대표적인 성능지표의 특성을 관찰함 으로서 부유동의 출구높이(s) 및 주유동의 팽창 정도(NPR1의 크기)가 추력편향의 주요 관계변수 임을 알 수 있다. 부유동의 출구높이가 작은 경 우 $(s=1 \mathrm{~mm})$ 가 편향이후의 최종추력 $(T)$ 의 손실 이 작게 나타난다. 아울러 이 경우에도 NPR1이 낮을수록 더 높은 추력편향 효과를 나타내어, 본 연구의 노즐 마하수에서는 초음속 제트가 과대팽 창 조건에서 현재의 기술이 적용가능하리라 판단 된다. 이에 따라, 동일한 시스템이 과소팽창되는 음속노즐에 응용되는 경우가 현재 당해기관에서 연구 중에 있다.

\section{IV. 결 론}

코안다 효과를 동반한 동축류 추력편향 제어 방법이 초음속 영역에 대하여 실험적으로 관찰되 었다. 고정확도를 갖는 다분력 시험장치를 이용 한 정량적 추력편향 특성과 숼리렌 유동가시화를 통한 정성적 특성이 관찰되어 다음과 같은 결론 이 얻어졌다.

(1) 부유동이 없는 단일 주유동의 경우에도 노 즐출구 아래에 위치한 코안다 벽면이 가까이 위 치할 때는 주유동의 후향계단 효과로 인하여 추 력편향이 발생한다.

(2) 부유동 공급 초기에는 일시적으로 편향각 이 감소되나, 부유동의 압력이 점차 커지면서 편 향각은 다시 증가하는 $\mathrm{V}$-자형 변화추세를 보인 다.

(3) 동일한 운동량플럭스비에서 추력편향각은 주유동의 압력이 작을수록, 그리고 부유동의 출 구높이가 작을수록 크다.

(4) 부유동의 출구높이가 상대적으로 작을 때 추력편향에 따른 추력손실이 적다.

(5) 본 연구에서 정의된 총합 추력편향효율을 기준할 때, 부유동 출구높이가 상대적으로 적은 경우에 그 효율이 더 크며, 본 연구의 노즐 마하 수에서는 초음속 제트가 과대팽창 조건에서 현재 의 기술의 효율적인 적용이 가능하다.

\section{후 기}

이 논문의 일부 내용은 한국연구재단의 기본 연구지원사업(과제번호: 2012R1A1A2006348)의 지 원을 받아 수행된 것이며, 이에 감사드립니다.

\section{References}

1) Deer, K. A., "Summary of Fluidic Thrust Vectoring Research Conducted at NASA Langley Research Center," AIAA 2003-3800, 2003.

2) Bevilaqua, P. M., Lee, John. D., "Design of Supersonic Coanda Jet Nozzles," AIAA 84-0333, 1984.

3) Mason, M. S., Crowther, W. J., "Fluidic Thrust Vectoring for Low Observable Air Vehicles," AIAA Paper 2004-2210, 2004.

4) Saghafi, F., Banazadeh. A., "Co-flow Fluidic Thrust Vectoring Requirements for Longitudinal and Lateral Trim Purposes," AIAA 2006-4980, 2006

5) Strykowski, P. J., Krothapalli, A., and Forliti, D. J., "Counterflow Thrust Vectoring of Supersonic Jets," AIAA Journal, Vol. 34, No. 11, pp. 2306 2314, 1996.

6) Alvi, F. S., Strykowski, P. J., "Forward Flight Effects on Counterflow Thrust Vector Control of a Supersonic Jet," AIAA Journal, Vol. 37, No. 2, pp. 279 281, 1999

7) Yoon, S. H., Jun, D. H., et al., "Experimental Study of Thrust Vectoring of Supersonic Jet Utilizing Co-flowing Coanda Effects," J. KSAS, Vol. 40, No. 11, pp. 927 933, 2012.

8) Song, M. J., Chang, H. B., et al., "Development of the High-Accuracy Multi-Component Balance for Fluidic Thrust Vectoring Nozzle of UAV," J. KSAS, Vol. 41, No. 2, pp. 142 149, 2013.

9) Flamm, J. D., Deere, K. A., et al, “Design Enhancements of the Two Dimensional, Dual Throat Fluidic Thrust vectoring Nozzle Concept," AIAA 2006-3701, 2006.

10) private communication with CAS Inc.

11) Gregory-Smith, D. G., Senior, P., "The Effects of Base Steps and Axisymmetry on Supersonic Jets over Coanda Surfaces," Int. J. Heat and Fluid Flow, Vol. 15, No. 4, pp. 291 298, 1994.

12) Carpenter, P. W., Smith, C., "The Aeroacoustics and Aerodynamics of 
High-Speed Coanda Devices, Part 2: Effects of Modifications for Flow Control and Noise Reduction," Journal of Sound and Vibration, Vol. 208, No. 5, pp. 803 822, 1997.
13) Berton, J. J., "Divergence Thrust Loss Calculations for Convergent-Divergent Nozzles: Extensions to the Classical case," NASA Technical Memorandum 105176, 1991. 